Sādhanā Vol. 39, Part 6, December 2014, pp. 1497-1507. (C) Indian Academy of Sciences

\title{
Low velocity impact behaviour of ultra high strength concrete panels
}

\author{
SMITHA GOPINATH*, R AYASHWARYA, V RAMESH KUMAR, \\ PRABHAT RANJAN PREM, A RAMA CHANDRA MURTHY, \\ C K MADHESWARAN and R NAGESH IYER
}

CSIR - Structural Engineering Research Centre, Taramani, Chennai 600 113, India e-mail: smithag@serc.res.in; smithagopinath13@yahoo.com

MS received 30 April 2013; revised 3 April 2014; accepted 11 June 2014

\begin{abstract}
This paper presents the results of an investigation carried out on Ultra High Strength Concrete (UHSC) panels subjected to low velocity projectile impact to assess impact resistance. UHSC panel of size $350 \times 350 \mathrm{~mm}$ and thickness $15 \mathrm{~mm}$ is studied under drop weight impact loading for three different pre-determined drop heights ranging from $100 \mathrm{~mm}$ to $300 \mathrm{~mm}$. The response of UHSC panel in terms of acceleration vs time is obtained experimentally. Numerical model has been developed to simulate the impact behaviour of UHSC panel. The Brittle cracking model is used to simulate the behaviour of UHSC panel under impact loading and to perform parametric studies by varying the volume fraction of steel fibres.
\end{abstract}

Keywords. Ultra high strength concrete; panel; drop weight test; impact analysis; ABAQUS.

\section{Introduction}

Ultra high strength concrete is a special type of concrete which is characterized by a low waterbinder ratio, high quality pozzolanic material, and without any coarse aggregates. Addition of steel fibres significantly improves the mechanical characteristics of concrete including tensile, flexural, fatigue and impact strengths. Additionally, inclusion of steel fibres reduces the brittleness of concrete and alters the mode of failure. Understanding of the impact resistance of concrete and especially of high strength concrete is very limited. Also there is no standardized test technique for testing concrete under impact. Zhang et al (2010) studied the characteristics of a drop weight impact machine that has been specifically designed for studying the dynamic behaviour of structural concrete samples. It was observed that the impact force is used to maintain the balance with the inertia force and only a small portion of impact is used to deform and

${ }^{*}$ For correspondence 
fracture. High strength concrete absorbs more energy under impact and it is a load rate-sensitivity material. Many researchers have used different impact machines, specimen configurations, and instrumentations and also adopted different analysis schemes (Farnam et al 2010; Ghouse et al 2011; Gayarre et al 2009; Wang et al 2011; Gopinath et al 2012; Abbas et al 2004; Xu et al 2004; Georgin \& Reynouard 2003; Habel \& Gaurvrean 2006; Zineddin \& Krauthammer 2007; Jiang \& Mirza 1988). Ong et al (1999) investigated fibre concrete slabs subjected to low velocity projectile impact to assess impact resistance. The main variables of the study were type of fibre and volume fraction of fibres. The types of fibres chosen were polyolefin, polyvinyl alcohol and steel. The volume fraction of fibres examined were $0 \%, 1 \%$ and $2 \%$. A total of 10 square slabs of size $1 \mathrm{~m}$ and $50 \mathrm{~mm}$ thickness were cast and tested. Test results indicated that hooked-end steel fibre concrete slabs have better cracking and energy absorption characteristics than slabs reinforced with other fibre types. Slabs reinforced with polyvinyl alcohol fibres exhibited higher fracture energy values compared to slabs reinforced with polyolefin fibres. Elavenil \& Samuel Knight (2012) investigated the dynamic behaviour of steel fibre reinforced concrete plates under impact loading with respect to displacement, velocity and acceleration. In the drop weight test, eighteen plate specimens were tested with three different thicknesses of 20, 25 and $30 \mathrm{~mm}$ and with three different steel fibre contents of $0.5,0.75$ and $1 \%$. Displacement versus time, velocity versus time and acceleration versus time behaviour for all the plates tested were studied. It was found that when the aspect ratio of fibres is 50 and 75, there is a marginal increase in energy absorption for change in fibre content from 0.5 to $0.75 \%$. There is a steep increase in energy absorption for a steel fibre content of $1 \%$ when the aspect ratio of fibre is 100 .

This paper consists of two parts: experimental program and numerical simulation. In the first part, drop weight impact test is carried out on six UHSC panels with $2 \%$ of steel fibres. The setup is made in accordance with the ASTM D7136/D7136M - 07. In the second part, numerical simulations of impact tests are comprehensively discussed and compared with the corresponding test data. The ABAQUS explicit finite element code is utilized to analyse the impact resistance of UHSC panels under low velocity drop weight impacts.

\section{Experimental program}

\subsection{Materials and mix proportion}

The materials used in the preparation of test specimens are ordinary Portland cement of grade 53 conforming to IS : 12269 - 1987 , Sand Grade I $(0.6-2.36 \mathrm{~mm})$ and Grade III $(0.075-0.15$ $\mathrm{mm}$ ), Silica fume, Quartz powder and steel fibre of diameter $0.4 \mathrm{~mm}$ and length $13 \mathrm{~mm}$. Table 1 defines the matrix mix proportion used for all samples (Prem et al 2012).

Table 1. Mix proportion.

\begin{tabular}{lcccccccc}
\hline \multirow{2}{*}{ Mix } & Cement & $\begin{array}{c}\text { Silica } \\
\text { fume }\end{array}$ & $\begin{array}{c}\text { Quartz } \\
\text { powder }\end{array}$ & $\begin{array}{c}\text { Sand } \\
\text { Grade I }\end{array}$ & $\begin{array}{c}\text { Sand } \\
\text { Grade III }\end{array}$ & $\begin{array}{c}\text { Steel fibre } \\
(\% \text { of binder })\end{array}$ & Water & $\begin{array}{c}\text { Sp \% } \\
\text { (Binder) }\end{array}$ \\
\hline Ratio & 1 & 0.25 & 0.40 & 0.71 & 0.30 & 2.0 & 0.22 & 3.25 \\
Quantity $\left(\mathrm{Kg} / \mathrm{m}^{3}\right)$ & 768.78 & 192.19 & 307.51 & 600.40 & 245.25 & 153.72 & 169.10 & $25.55^{*}$ \\
\hline
\end{tabular}

*litres $/ \mathrm{m}^{3}$ 


\subsection{Specimen preparation, casting and curing}

A pan type mixer (Eirich mixer of $300 \mathrm{~kg}$ capacity) was used to mix the UHSC mixture.The advantage of the mixer is its ability to rotate the mixing drum and the blades simultaneously at the same time, to provide a uniform blending. The dry binder powder was poured in the mixing pan and dry mixing was done at slow speed of 10 minutes. Around $30 \%$ of the water and the super plasticizer were added and the level of mixing was increased to medium, which was continued for another 10 minutes, again 50\% of the water and SP were added to inhibit homogeneity in the mix at high speed for 10 minutes. The steel fibres were added to the mix manually through the open slit available at the top of the drum. Finally, remaining $20 \%$ of the SP and water were added and the drum was rotated at a very high speed for 10 minutes.

After mixing, the fresh concrete was transferred into steel moulds (which were previously oiled) in three layers and compacted for 30 seconds each using a vibrating table shown in figure 1 . The aim of vibrating the filled moulds is to properly compact the materials, to make sure that the fibres are distributed without segregation. The specimens were given a proper finishing ensuring uniformity and perfect appearance. The specimens were demoulded after a time interval of $24 \mathrm{~h}$. The samples after demoulding were kept in water for 7 days after which they were exposed to hot air curing at $200^{\circ} \mathrm{C}$ for 2 days. After the hot air regime, the samples were then continued with water curing till the period of testing.

\subsection{Mechanical properties}

Compression test on UHSC was carried out on cubic specimens of size $70 \mathrm{~mm}$. The strength was recorded at 7,14 and 28 days. The average reading of the tested cubes was represented as the strength at the respective age as shown in table 2 .

The split tensile test was carried on cylindrical specimens of $100 \mathrm{~mm}$ diameter and $200 \mathrm{~mm}$ height at the age of 28 days. Five cylinders were tested and the mean value of the recorded data is reported (table 3 ).

\section{Drop weight impact test}

The test set-up consists of a supporting frame on which the specimen is placed, an impact mass of $20 \mathrm{~kg}$ with $20 \mathrm{~mm}$ diameter impact set-up as shown in figure 2, is made to impact from a

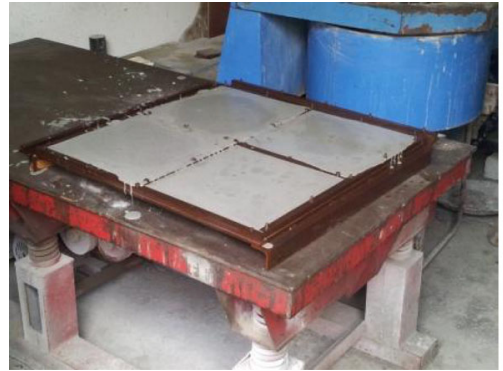

(a)

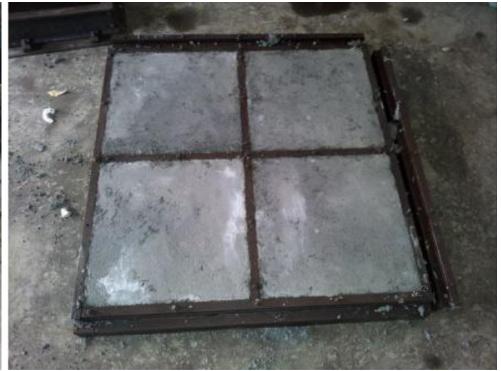

(b)

Figure 1. Specimen preparation. (a) Pouring of UHSC into moulds; (b) Hardened UHSC before demoulding. 
Table 2. Compression test results.

\begin{tabular}{lcc}
\hline Day of testing & Force $(\mathrm{kN})$ & Strength $(\mathrm{MPa})$ \\
\hline $7^{\text {th }}$ day & 795.61 & 162.37 \\
$14^{\text {th }}$ day & 915.52 & 186.84 \\
$28^{\text {th }}$ day & 934.61 & 190.74 \\
\hline
\end{tabular}

Table 3. Split tensile test results.

\begin{tabular}{lc}
\hline Force $(\mathrm{kN})$ & Split tensile strength $(\mathrm{MPa})$ \\
\hline 717.55 & 22.84 \\
730.13 & 23.24 \\
710.57 & 22.61 \\
736.90 & 23.45 \\
725.86 & 23.10 \\
Average value $=$ & $\mathbf{2 3 . 0 5}$ \\
\hline
\end{tabular}

pre-determined height using a pulley and rope arrangement which is being made to pass through the tubular structure attached over the supporting frame as shown in figure 3 , in order to guide the free fall of impact mass. The specimen was hinged over the supporting frame by means of fastening C-clamps over the corners as shown in figure 4. This set-up is made in accordance with the ASTM D7136/D7136M - 07.

Drop weight impact loading is applied by freely dropping the impact mass from different heights of 100, 200 and $300 \mathrm{~mm}$. The acceleration time history is recorded using an accelerometer mounted on the top of the specimen which is further connected to a Data Acquisition

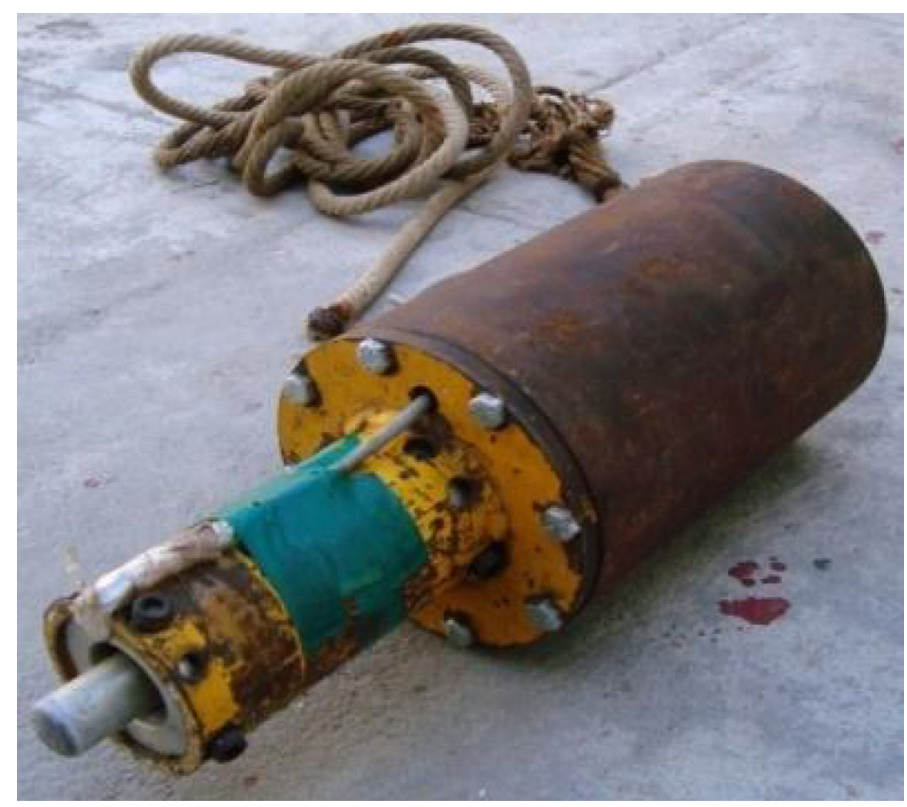

Figure 2. Drop mass $20 \mathrm{~kg}$. 




Figure 3. Drop weight testing frame.

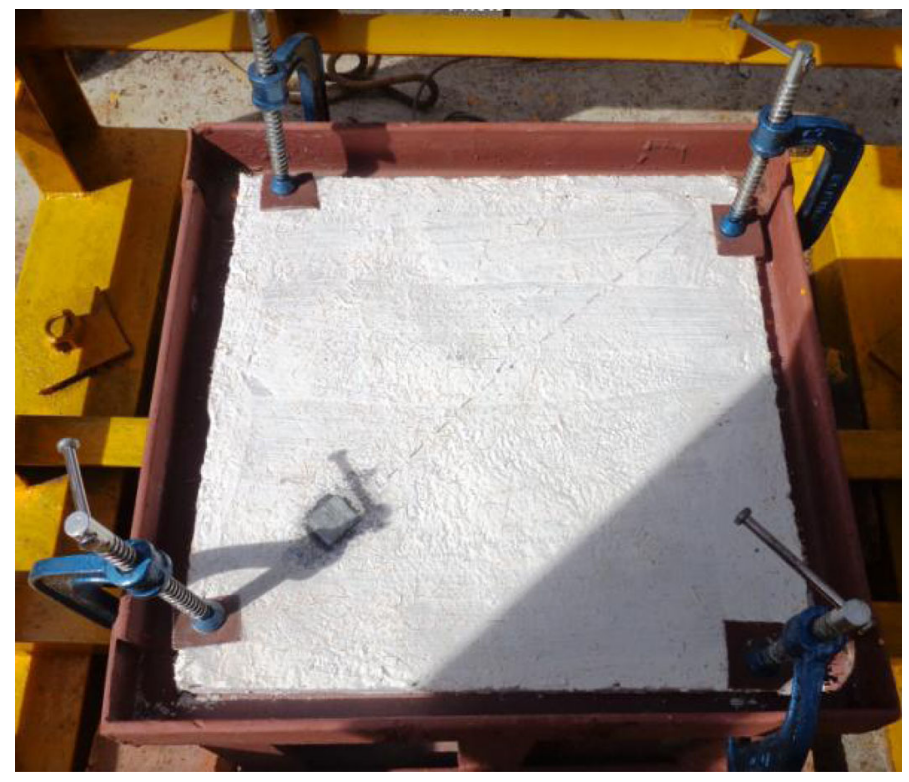

Figure 4. Test specimen. 
System which is capable of recording velocity data and it was in accordance with the Minimum Instrumentation Requirements, of Test Method D3763.

\section{Test results}

The impact test was conducted and the results were recorded. Impact damage/failure pattern were recorded for each drop height. No impression occurred for a drop height of $100 \mathrm{~mm}$. No patterns were observed even when the load cell was dropped for the second and the third time. All the three test specimens showed the same results. Similar results were obtained for the 200 $\mathrm{mm}$ drop. Finally, under the drop height of $300 \mathrm{~mm}$ in the first trial there was a slight impression which got deeper in trial two. And in the third trial, the load cell punched fully into the panel. The responses for typical panel for all drop height is shown in figure 5 .

\section{Numerical investigations}

The drop weight impact tests on ultra high strength concrete (UHSC) were simulated through commercially available three-dimensional nonlinear dynamic finite element code, ABAQUS. Both the steel impactor and ultra high strength concrete (UHSC) have been modelled with 8-node solid elements.

\subsection{Details of the drop weight}

The impact mass along with the load cell and the impact tup is modelled as a rigid material as shown in figure 6. The drop weight hammer made of steel is modelled as a rigid material as the deformation in the impactor is not expected. The Young's modulus of $210 \mathrm{GPa}$ and Poisson's ratio of 0.2 was given as input in the modelling.

The drop mass is with hemispherical nose with impact head of diameter of $20 \mathrm{~mm}$, shank length $\mathrm{l}_{1}-2$ in $50 \mathrm{~mm}$, nose edge length $\mathrm{l}_{2}$ of $10 \mathrm{~mm}$. The load cell is with a diameter of $120 \mathrm{~mm}$ and $150 \mathrm{~mm}$ length and is attached to a impact mass of $150 \mathrm{~mm}$ diameter and $250 \mathrm{~mm}$ length.

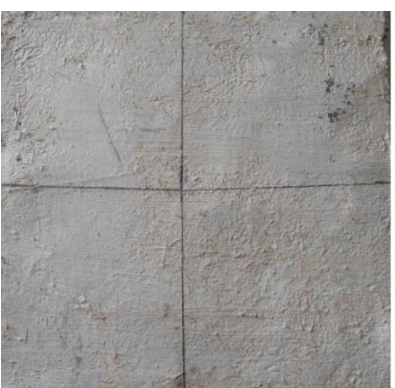

(a)

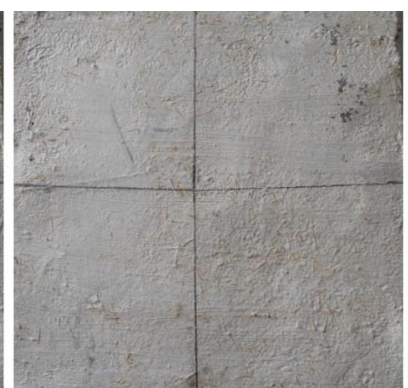

(b)

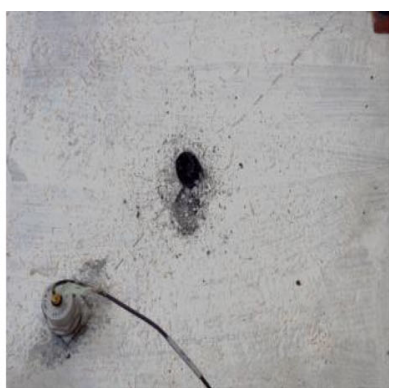

(c)

Figure 5. Responses of panel. (a) $100 \mathrm{~mm}$ drop; (b) $200 \mathrm{~mm}$ drop; (c) $300 \mathrm{~mm}$ drop. 


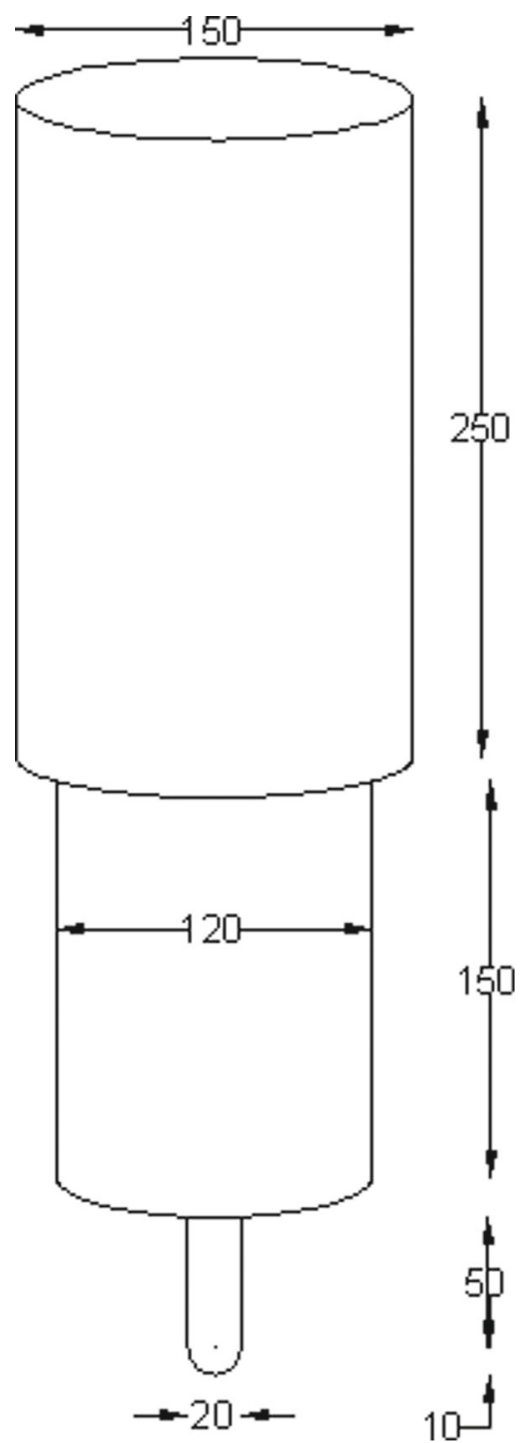

Figure 6. Drop mass geometry details (all dimensions are in $\mathrm{mm}$ ).

\subsection{Details of the target}

The development of the FE model (figure 7) for the low velocity impact simulations in ABAQUS involves the modelling of the composite material and the modelling of the impactor with adequate contact definitions. The UHSC composite material is modelled as a plain concrete slab in which the fibres are oriented randomly. Only half of the panel is modelled due to symmetry.

The mesh size used for analysis is $35 \times 35 \mathrm{~mm}$. The target is meshed using solid 8 noded elements of type C3D8R. Each node has 3 degrees of freedom. The target is hinged at the bottom surface. The impact is defined using general contact algorithm where the top surface of the panel is defined as the master surface and the impactor as the slave surface. Brittle cracking model 


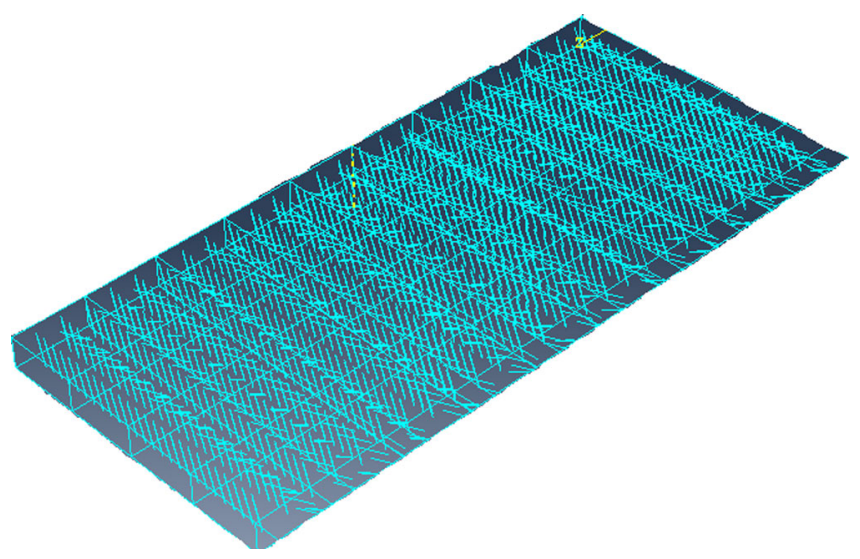

Figure 7. FE model of the UHSC panel.

is defined by giving the elasto-plastic behaviour of the material and the direct cracking failure strain is given as input under brittle failure option.

\subsection{Results}

In this part, the experimental and numerical results are compared. The acceleration-time graph found experimentally and numerically for $100 \mathrm{~mm}$ drop height is shown in figure 8 . The maximum peak value of acceleration for experimental value is $29.45 \mathrm{~mm} / \mathrm{sec}^{2}$ which occurred during the $26.84^{\text {th }} \mathrm{ms}$ of impact and that for numerical simulation is $21.34 \mathrm{~mm} / \mathrm{sec}^{2}$.

In figure 9, the acceleration-time graph found experimentally and numerically for $200 \mathrm{~mm}$ drop height are shown and it can be observed that the experimental result gave a maximum peak acceleration of $29.45 \mathrm{~mm} / \mathrm{sec}^{2}$ at $26.74 \mathrm{~ms}$ and the numerical result gave a peak acceleration of $22.97 \mathrm{~mm} / \mathrm{sec}^{2}$.

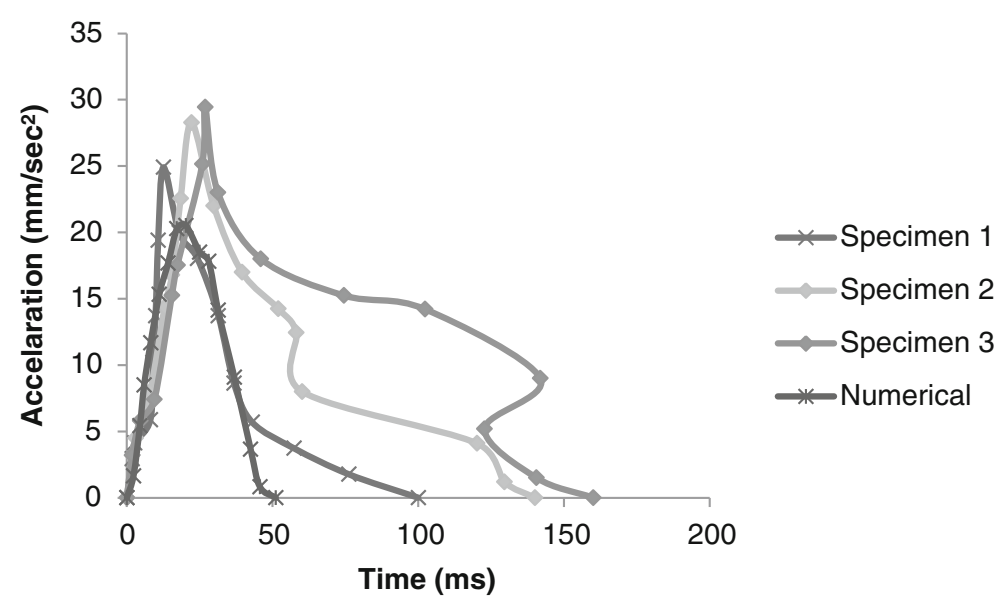

Figure 8. Acceleration-time for $100 \mathrm{~mm}$ drop height. 


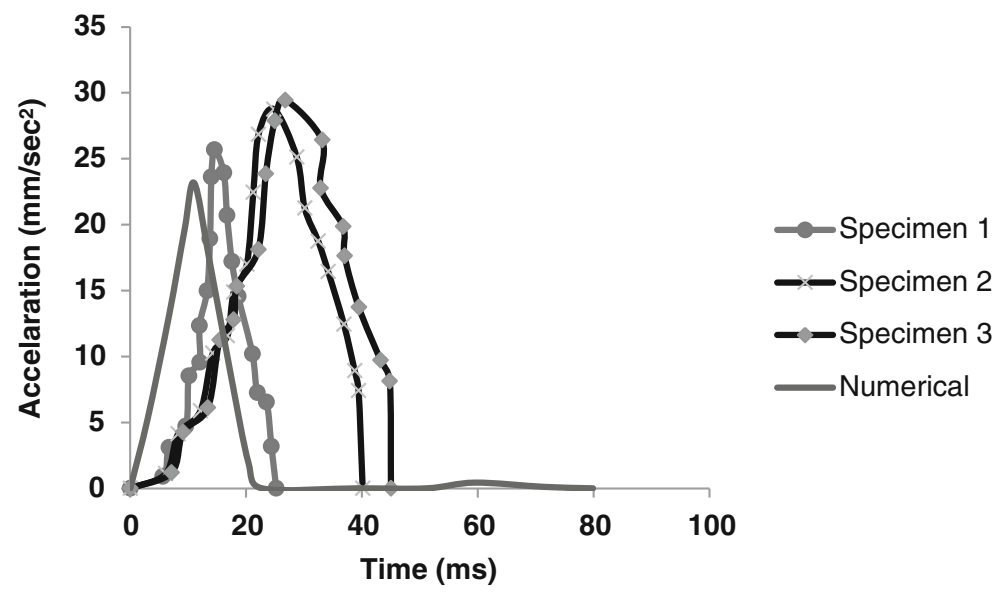

Figure 9. Acceleration-time for $200 \mathrm{~mm}$ drop height.

In figure 10, the variation of acceleration with time found experimentally and numerically is represented for $300 \mathrm{~mm}$ drop. It is observed that the peak value is $30.12 \mathrm{~mm} / \mathrm{sec}^{2}$ occurred at $16.52^{\text {th }} \mathrm{ms}$ for experimental result and it is $24.83 \mathrm{~mm} / \mathrm{sec}^{2}$ for numerical solution. As per Oliver Martin (2010), brittle cracking model assumes that the compressive behaviour of concrete is always linear elastic, which does not resemble reality and is a limitation of the model. It is most accurate in applications where the brittle behaviour dominates such that the assumption of the material is always linear elastic in compression is adequate. This is not really the case for missile impact analysis where the reinforced concrete slab experiences the plastic behaviour predominantly. In the present numerical study, up to a velocity of $1.98 \mathrm{~m} / \mathrm{s}$ it is observed that the brittle cracking model can be employed for analysis. But for a velocity of $2.42 \mathrm{~m} / \mathrm{s}$, the experimental and numerical graphs do not coincide completely.

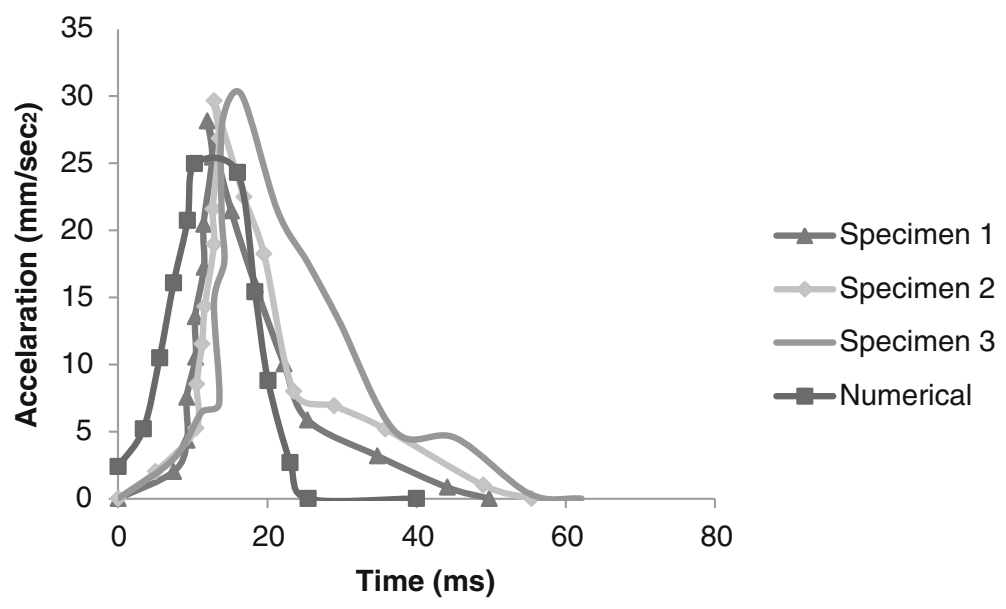

Figure 10. Acceleration-time for $300 \mathrm{~mm}$ drop height. 


\section{Conclusions}

Drop weight impact analysis has been conducted to find the ability of UHSC to resist impact loads. For UHSC panels having $2 \%$ of steel fibres, the $20 \mathrm{~kg}$ drop mass allowed to impact the panel at $100 \mathrm{~mm}$ drop height did not show any change for three consecutive drops for all three specimens. Similar observations were made for $200 \mathrm{~mm}$ drop height for all three specimens. In the case of $300 \mathrm{~mm}$ drop height, the first drop created a slight impression which became deeper in the second drop. In the third and final drop, the impact tup completely penetrated into the panel. The variation of acceleration with time for various drop heights were studied experimentally and numerically and both the studies gave similar results. Parametric studies were conducted by varying the volume fraction of fibres to $0.5 \%$ and $1 \%$. The total energy values for 100,200 and $300 \mathrm{~mm}$ drop heights were obtained from the Finite Element models.

\section{Acknowledgements}

Authors thank the staff of Computational Structural Mechanics Group and Advanced Materials Laboratory, CSIR-SERC for support during the investigations. This paper is being published with the kind permission of the Director, CSIR-SERC.

\section{References}

Abbas H, Gupta N K and Alam M 2004 Nonlinear response of concrete beams and plates under impact loading. Int. J. Impact Eng. 30: 1039-1053

Elavenil S and Samuel Knight G M 2012 Impact response of plates under drop weight impact testing. Daffodil International University. J. Sci. Technol. 7(1): 1-11

Farnam Y, Mohammadi S and Shekarchi M 2010 Experimental and numerical investigations of low velocity impact behaviour of high performance fibre reinforced cement based composite. Int. J. Impact Eng. 37: 220-229

Gayarre F L, Albert Domingo, Carlos Lazaro, Caelos Lopez Colina and Maria Pelufo 2009 Model for the behaviour of steel fibre reinforced concrete in plate elements. Proceedings of the International Association for Shell and Spatial Structures, Spain, 2965-2980

Georgin J F and Reynouard J M 2003 Modeling of structures subjected to impact:concrete behaviour under high strain rate. Cem. Concr. Compos. 25: 131-143

Ghouse M D, Lakshmana Rao C and Rao B N 2011 Numerical modelling of failure of cement concrete using a unit cell approach. Sadhana 36(1): 35-51

Gopinath S, Madeswaran S, Rama Chandra Murthy A, Barkavi T and Nagesh R Iyer 2012 Drop weight impact analysis of fabric reinforced concrete. SERC Research Report No. CSD-MLP134-RR-01

Habel K and Gaurvreau P D 2006 Static and impact behaviour of concrete members rehabilitated with UHPFRC overlay. $2^{\text {nd }}$ International Symposium on Advances in Concrete through Science and Engineering, 11-13, September, Quebec City, Canada

Jiang P J and Mirza F A 1988 An Elasto-plastic constitutive model for concrete. Int. J. Solids Struct. 24(7): $705-722$

Oliver Martin 2010 Comparison of different constitutive models for concrete in ABAQUS/explicit for missile impact analyses. JRC Scientific and Technical Reports

Ong K C G, Basheerkhan M and Paramasivam P 1999 Resistance of fibre concrete slabs to low velocity projectile impact. Cem. Concr. Compos. 21: 391-401

Prem P P, Bharathkumar B H and Nagesh R Iyer 2012 Mechanical properties of ultra high performance concrete. World academy of Science, Engineering and Technology, Issue 68, August 2012, Malaysia, 1969-1978 
Wang Z L, Shi J M and Wang J G 2011 On the strength and toughness properties of SFRC under static dynamic compression. Compos. Part B 42: 1285-1290

$\mathrm{Xu}$ H, Mindess S and Joseph I D 2004 Performance of plain and fibre reinforced concrete panels subjected to low velocity impact loading. $6^{\text {th }}$ RILEM Symposium on Fiber-Reinforced Concretes (FRC) - BEFIB, 20-22, September, Varenna, Italy

Zhang X X, Ruiz G and Yu R C 2010 A New drop-weight impact machine for studying fracture processes in structural concrete. Strain An Int. J. Experimental Mech. 46: 252-257

Zineddin M and Krauthammer T 2007 Dynamic response and behavior of reinforced concrete slabs under impact loading. Int. J. Impact Eng. 34: 1517-1534 